\title{
Sevim Burak's Protest Theatre: Understanding Sevim Burak Through Adorno
}

\author{
Mehmet Zeki Giritli ${ }^{1}$ (b)
}

'Lecturer Dr., Koç University, College of Social Sciences and Humanities, İstanbul, Turkey

\section{ORCID: M.Z.G. 0000-0002-3421-4205}

Corresponding author / Sorumlu yazar: Mehmet Zeki Giritli,

Koç University, College of Social Sciences and Humanities, İstanbul, Turkey

E-mail/E-posta: mgiritli@ku.edu.tr

Submitted/Başvuru: 08.02.202

Revision Requested/Revizyon Talebi:

21.02.2021

Last Revision Received/Son Revizyon:

21.02.2021

Accepted/Kabul: 29.03 .2021

\section{Citation/Atıf:}

Giritli, Mehmet Zeki. “Sevim Burak's Protest Theatre: Understanding Sevim Burak Through Adorno" Tiyatro Eleştirmenliği ve Dramaturji Bölümü Dergisi 32, (2021): 57-74. https://doi.org/10.26650/jtcd.877058

\section{ABSTRACT}

The purpose of this article is to explore Sevim Burak's theatre through Adorno's "negative dialectics" and "culture industry" theories. The article claims that Burak's theatre is revolutionary in the sense that it challenges the traditional norms of theatre based on representation of real life. Burak, in contrast to traditional theatrical forms, creates a form negating real life and resisting against any form of mimetic representation. However, this does not turn her theatre into an apolitical, anti-social, or extremely individualistic one as Burak's form is rooted in the social and parental background of the playwright. However, her unique form was expelled from the literary circles and has long been neglected by scholars, which the article claims is the result of the reflections of Adorno's "culture industry" on the literary scene in Turkey. Thus, the final claim of the article is that Burak's theatre is revolutionary and a protest not due to its subject matter but to its form.

Keywords: Sevim Burak, Protest theatre, Form in theatre, Culture industry, Negative dialectics 


\section{Introduction}

Despite the common reluctance to classify Sevim Burak's art, especially her theatre as part of a particular art movement or school, Burak's theatre reflects characteristics of anti-realist movements led by twentieth century artistic modernism. As early as 1917, Dow defined artistic modernism as "an inclusive name applied to the many forms of rebellion against the accepted and the traditional. A modernist likes to be thought a rebel". ${ }^{1}$ This defined characteristic has been revisited by many others since then, and Sevim Burak as an artist could be regarded as the embodiment of this "rebellion" in the history of Turkish literature and theatre. This does not necessarily imply an obligation to categorize Burak's art; however, evaluating an artist's work without a conceptual framework would fail to ensure a satisfactory result. It would not be wrong to claim that this has mostly been the case in the limited scope of literature on Sevim Burak.

Bedia Koçakoğlu’s “Aşkın Şizofrenik Hali Sevim Burak” [Sevim Burak: Schizophrenic State of Love] ${ }^{2}$ and "Sevim Burak'ı Besleyen Damarlar" [The Streaks that Fed of Sevim Burak]', Ahmet Kılınç's article "Sevim Burak'ın Küçürek Öykücülüğ̈̈” [The Short Story Storytelling of Sevim Burak $]^{4}$ are a few examples which aimed to explore Burak's works mostly relying on close reading and general characteristics of Burak's art, failing to link the works to a conceptual background. This resulted in repetitive plot summaries of Burak's works, mostly her short stories, rather than an analysis of the author's artistic style. However, it should be noted that Nilüfer Güngörmüş’s feminist reading ${ }^{5}$, Beliz Güçbilmez's reading of Sevim Burak's works as pieces of "minoritarian literature" ${ }^{6}$, Zafer Aracagök and Burcu Yalım's endeavor to locate Sevim Burak in the world literature through their comparative article on Burak and Sarah Kane ${ }^{7}$, Şeyma Gümüş's reading of Sevim Burak through queer theory ${ }^{8}$ have paved the way for more innovative and analytical approaches to Sevim Burak's art. Mustafa Demirtaş's work Postyapisalcı Edebiyat Kuramı [Poststructuralist Theory in Literature] ${ }^{9}$ in which the author attempted to explore Burak's works through a poststructuralist perspective is worth

1 Arthur Wesley Dow, "Modernism in Art", The American Magazine of Art 8 (1917), 113-116.

2 Bedia Koçakoğlu, Aşkın Şizofrenik Hali Sevim Burak (Konya: Palet Yayınları, 2009).

3 Bedia Koçakoğlu, “Sevim Burak’1 Besleyen Damarlar”, Selçuk Üniversitesi Edebiyat Fakültesi Dergisi 17 (2007), 45-59.

4 Ahmet Kılınç, “Sevim Burak’ın Küçürek Öykücülüğ̈̈”, Turkish Studies (2011), 1983-1994.

5 Nilüfer Güngörmüş, "Sanatçının Annesinin Kızı olarak portresi”, YKY Feminizm Üzerine Konuşmalar Dizisi, Kadınlar, Kimlikler, Hafizalar, Psikanaliz ve Feminizm Paneli (2005).

6 Beliz Güçbilmez, “Tekinsiz Tiyatro: Sahibinin Sesi/Sevim Burak’ın Metninde Teatrallik ve Minör Sesin Temsili”, Tiyatro Araştırmaları Dergisi 16 (2003), 4-17.

7 Zafer Aracagök, Burcu Yalım, "Spectacle, Speculative, Spectile: Situations in Sarah Kane, Sevim Burak etc.”, Third Text (2010), 437-444.

8 Şeyma Gümüş, “Sevim Burak’ın Queer Nesneleri: Yanık Saraylar'da Eşya-İnsan İlişskileri, Öznellik ve Ötekilik”, Monograf 14 (2020), 60-82.

9 Mustafa Demirtaş, Postyapısalcı Edebiyat Kuramı: Sevim Burak, Edebiyatta Bir Tekillik Düşünürü (Otonom Yayınları, 2015). 
mentioning here. However, the majority of this work focuses on the historical development of poststructuralist movement rather than its implications on Sevim Burak's art. Thus, the primary motive for this article is to contribute to the limited conceptual analysis of Sevim Burak's oeuvre and to acknowledge Burak's relatively neglected theatrical works, compared to her short stories, in the light of Adorno's negative dialectics and culture industry theories.

Sevim Burak was born in Ortaköy, İstanbul in 1931 to a Muslim father and a Jewish mother, a symbiosis which influenced her whole life as well as her writing style. Burak spent the first 21 years of her life in Kuzguncuk, a neighbourhood in the Anatolian side of Istanbul, which was mostly inhabited by Jewish people, and known as "Little Paris" due to its cosmopolitan atmosphere. ${ }^{10}$ After graduating from Deutsche Schule Istanbul (German School of Istanbul), a private high school in Beyoğlu, Burak did not pursue higher education, and started working as a model and then as a seamstress. ${ }^{11}$ It is a well-known fact that Burak used to pin the pieces of her works on the curtains, and then rearranged them in various orders to create a whole work, a style generally associated with her career as a seamstress. Sevim Burak started taking literature lessons from the renowned novelist of the time, Peyami Safa whom she met at a beauty contest in 1947. Bedia Koçakoğlu, based on Karaca Borar's (Sevim Burak's son) remarks, underlines that Peyami Safa, who was then married, was in love with Sevim Burak. ${ }^{12}$ Burak then started her writing career in the 1950's as a short story writer.

When Sevim Burak started to publish her first short stories in $1950^{13}$, the literary community in Turkey was mostly dominated by socialist realism, and Burak's debut stories tended to be more realistic and representative, assumedly under the influence of this literary monopoly. In an interview dated 1965, Burak referred to these first stories as "an attempt to play up to the common expectations ". ${ }^{14}$

Only in 1965, Burak found the opportunity to publish Yanık Saraylar [Burnt Palaces], her most provocative work until then, and a work exemplary of her style, unlike the stories she published during the 1950's. As Güngörmüş puts it “it [the book] was met with both great acclaim but also with a bit of amazement... Sevim Burak stands out as a writer who did not appear to quite fit in with the literary climate of her time. She was an 'eccentric'." ${ }^{15}$ "Not fitting in with the literary climate of her time" precipitated the author's expulsion from the literary circle, leading to her long-lasting resentment towards the monopoly when Yanık

10 Bir Usta, Bir Dünya: Sevim Burak. One Master, One World: Sevim Burak, Ed. Filiz Özdem. (İstanbul, Yapı Kredi Yayınc1lık, 2013), 23.

11 Koçakoğlu, Aşkın Şizofrenik Hali Sevim Burak, 30.

12 Ibid., 39.

13 "Hirsız”, Ulus, No: 10339, 12.04.1950, “İntihar”, Ulus, No: 10380, 23.05.1950, "Köşe Kapmaca”, Ulus, No: 1440, 22.07.1950, “Gecekondunun Zaferi”, Ulus, No: 10352, 11.11.1950, “Nişanlı Kız”, Milliyet, S.94, 04.08.1950, "Büyük Günah", Yeni İstanbul, S. 267, 24.08.1950"

14 Koçakoğlu, Aşkın Şizofrenik Hali Sevim Burak, 69.

15 Nilüfer Güngörmüş, foreword to Bir Usta, Bir Dünya: Sevim Burak. One Master, One World: Sevim Burak, 7. 
Saraylar [Burnt Palaces] was not deemed worthy of Sait Faik Short Story Award in 1966. She wrote of her resentment towards the decision in a letter to Güzin Dino dated 1980. (Koçakoğlu mentions this letter as "written to Karaca Borar" ", but in the 2014 publication of Sevim Burak's letters, this letter is addressed to Güzin Dino):

Yanik Saraylar [Burnt Palaces] wasn't awarded because they were afraid that I would be spoilt if I received the prize. The award was given to a bad author, who published a few books ten years ago. It is rumoured that he doesn't have money to buy wood, and that is the reason... Memet Fuat sent a letter to the jury declaring that he would resign if Yanik Saraylar [Burnt Palaces] were not awarded... Both Memet Fuat's letter and my book were excommunicated. Memet Fuat resigned from the jury. ${ }^{17}$

"Yanık Saraylar" [Burnt Palaces] consists of six short stories which share some common characteristics both in terms of the themes and the style. The influence of the writer's Jewish background is visible in each story; however, Burak was interested not only in storytelling in "Burnt Palaces" but also in experimenting with the writing style. The jury members of the prestigious Sait Faik Short Story Contest that year were Memet Fuat, Tahir Alangu, Behçet Necatigil, and Haldun Taner. Although avant-garde styles were emerging in the 1960's and Burak's story book was identified as the "literary event of the year", the jury decided to award Cengiz Yörük's book “A Camel in the Desert”. Yörük's stories depicted village life in the Aegean side of Turkey and his style was far away from avant-garde, mostly representing the popular "village literature" as explained by Karpat. Sevim Burak believed that Burnt Palaces was excommunicated by the jury due to its avant-garde style which was not based on representative realism. Memet Fuat's resignation from the jury supports Sevim Burak's assumption. The winner of the award Cengiz Yörük published his last book the following year and continued his life as a tradesman.

Only after seventeen years in 1982, this resentment was partially restored and Burak returned to the literary scene not only as a short story author but also as a playwright, having proved to be a unique character with her theatrical style in the history of Turkish theatre. Her second short story collection African Dance was published in 1982, consisting of fifteen short stories, followed by her theatrical masterpiece His Master's Voice published in the same year. The play was based on her short story Ah Ya Rab Yehova [Oh God! Jehova].

Burak had had a heart disease since she was ten, and she had to deal with it throughout her life. She passed away in 1983 while preparing to publish a novel Ford Mach I, another short story collection Palyaço Ruşen [Clown Ruşen], two theatre plays Everest My Lord and Here is the Head, Here is the Body, Here are the Wings, all of which were published after her death. Her son Karaca Borar published Sevim Burak's letters addressed mostly to him, in 1990 (fifth

16 Koçakoğlu, Aşkın Şizofrenik Hali Sevim Burak, 71.

17 Sevim Burak, Mach One'dan Mektuplar (İstanbul: Palto Yayınları, 2014, 5. Bask1), 31. 
publishing in 2014) which provides valuable information about Burak's literary life between 1965-1983 as well as her personality and artistic style.

\section{Burak's Theatre and Adorno's Aesthetic Theory}

Sevim Burak's theatre can be identified with ascesis and vigilance. Burak declared that she had worked for seven years on transforming her short story "Ah Ya Rab Yehova" [O God Jehova] into a theatre play "Sahibinin Sesi" [His Master's Voice], which turned out to be one of the most innovative and experimental plays in the history of Turkish theatre. In a sense, the play proved to be a stance against "culture industry", a term borrowed from Adorno.

The protagonist in "His Master's Voice”, Bilal lives in a neighbourhood mostly inhabited by minorities. He is in an emotional relationship with Zembul who is Jewish; however, he is unwilling to get married to her although Zembul is pregnant. He is nervous that the neighbours would force him to get married to Zembul, which drives Bilal even more paranoid, adding to his already suspicious character. Bilal is also a draft dodger and uses Muzaffer Seza's identity in fear of getting captured by the police. Muzaffer Seza is a military pilot who passed away in an explosion. Bilal's paranoid feelings climb up to an extreme upon Zembul's giving birth to her baby. He believes that the baby belongs to someone else and that Zembul is cheating on him. He starts to be suspicious from all of his neighbours which turns into xenophobia. He ends up seeing delusions and the ghost of the dead soldier, which comes to a point where he cannot distinguish dreams from reality. Meanwhile, he pricks his heel with a needle, and the needle starts moving from his heel up to his heart throughout the rest of the play, and Bilal's mental health deteriorates to a point in which he starts making plans to set fire to the whole neighbourhood.

Before proceeding with specific passages from the play, it would be useful to explain Adorno's approach to art and its relevance to Sevim Burak. A near contemporary of Sevim Burak, Theodor Adorno (1903-1969) was one of the most significant philosophers of the twentieth century and a prominent figure in the Institute of Social Research in Frankfurt, which was to lead the Frankfurt School movement. ${ }^{18}$ In the Dialectic of Enlightenment, Adorno and Horkheimer brought forward one of the most critical evaluations of the Enlightenment and modern western society, proposing that the existence of fascist ideologies proved a dilemma inherent within the Enlightenment. ${ }^{19}$ For Ferda Keskin "Posing a criticism to the modern society requires to criticize the society from within. This could be achieved only through a criticism

18 Lambert Zuidervaart, "Theodor W. Adorno", The Stanford Encyclopedia of Philosophy, Ed. Edward N. Zalta (Winter 2015 Edition), https://plato.stanford.edu/archives/win2015/entries/adorno/.

19 M. Horkheimer \& T.W. Adorno, Dialectic of Enlightenment: Philosophical Fragments, Ed. G.S.Noerr, trans. E. Jephcott (Stanford: Stanford University Press, 2002), 63-93. 
based on the norms of the society being criticized." ${ }^{20}$ In accordance with this interpretation, it could be claimed that Adorno aimed at a real criticism based on the existing norms rather than a transcendent one based on the norms of a utopian society.

The focus of this article will not be on Adorno's criticism of the Enlightenment though, due to the scope of the topic; however, his ideas on modern art, aesthetics, and "culture industry" will be applied to Sevim Burak's theatre and Burak's stance within the Turkish literary circle.

In Aesthetic Theory, Adorno defines the position of modern art as "the social antithesis of society" 21 , which endows modern art with an autonomous power. This autonomous power of art in Adorno is obviously a response to Georg Lukàcs who claimed that content should determine form in literature, and the ideology of the author should determine the value of the literary work. In "Realism in the Balance", Lukàcs, who defined "socialist realism" as the only decent artistic form, argued that "the art they [modernists] create remains abstract and one-dimensional" 22 and abstraction for Lukàcs could only be used as a secondary tool to reflect "objective social conditions". Thus, the primary purpose of art and literature should be to represent the real world as objectively as possible. Lukàcs further claimed that modernism destroyed not only the traditional art forms, but also the literature itself. This restrictive and bigoted approach to art and literature caught flak from Walter Benjamin, Ernst Bloch, Bertolt Brecht, and obviously Adorno, a debate which culminated in one of the long-lasting segregations in the art history. Adorno in response to Lukàcs claimed "Instead of recognizing the objective function of formal elements in determining the aesthetic content of modern art, he willfully misinterprets them as arbitrary ingredients added by an over-inflated subjectivism... He remains indifferent to the philosophical question of whether the concrete meaning of a work of art is in fact identical with the mere reflection of objective reality, a vulgar-materialist shibboleth to which he doggedly clings. " 23

Taking into consideration the fact that Lukàcs' understanding of realism was widely adopted by the literary circle in Turkey during the 1950s and 60s through the "village literature" which focused on representing the village life in Turkey, the reason behind Sevim Burak's expulsion from the literary scene turns out to be more obvious. Burak's art, although deeply influenced by her Jewish background and the socio-historical factors, aims neither to represent a so-called objective reality nor to convey a message or an ideology, but rather to present "situations" of the humankind, in Jaspers ${ }^{24}$ words through a unique artistic form.

20 Ömer Naci Soykan, Ferda Keskin \& Besim F. Dellaloğlu, "Adorno ve Yapıtı" in Adorno: Kitle, Melankoli, Felsefe, Ed. E. Efe Çakmak (İstanbul: Yapı Kredi Yayınları, 2003), 37.

21 T.W. Adorno, Aesthetic Theory, trans. R. Hullot-Kentor (Minneapolis: University of Minnesota Press, 1997), 8.

22 Georg Lukàcs, "Realism in the Balance" in Aesthetics and Politics, Ed. Ronald Taylor, (London; New York: Verso, 1980), 28.

23 Theodor Adorno, "Reconciliation Under Duress" in Aesthetics and Politics, Ed. Ronald Taylor, (London; New York: Verso, 1980), 151.

24 Chris Thornhill and Ronny Miron, "Karl Jaspers", The Stanford Encyclopedia of Philosophy, Ed. Edward N. Zalta (Spring 2020 Edition), https://plato.stanford.edu/archives/spr2020/entries/jaspers/. 
It would not be wrong to claim that the expulsion of non-representational or experimental works of literature as Burak's is still a tendency in some literary circles in Turkey. To clarify this claim further, major literary magazines in Turkey such as Notos ${ }^{25}$ and Varlık ${ }^{26}$ tend to expect new short story writers to fit into certain stylistic features in writing a story to give a social message or at least to follow the linear plot development with a dénouement, a climax, and a resolution, an approach which could easily be seen on the review columns of these magazines. Although this does not necessarily mean that experimental works are totally expelled from these magazines, the sample reviews clearly put forth the expectations of the literary circle in charge of these columns. The aim of this claim is not to prioritize one style over the other, but to underline the unequal approach in the reception of the experimental works. Obviously, not all experimental works prove to be satisfactory; however, adopting the stylistic features of realist literature as the only medium would possibly result in the ignorance of satisfactory experimental works as well. Sevim Burak had to fight with this approach in the 1960s, and it is highly possible that she started writing plays due to the relatively free space of theatre. Demirtaş highlights this as well:

It is not hard to comprehend the extremely difficult situation Sevim Burak faced in a literary scene where socialist realist literature had the predominant role. Burak's expulsion from the literary circles is understandable taking into consideration the fact that the author figure in Turkey was always considered as part of the intellectual figure and that the function of being an author was evaluated within the scope of social consciousness and social mission... However, it is not understandable why formalist authors who questioned the role of language in their works- such as Leyla Erbil-neither took part on the side of Burak nor supported her art. ${ }^{27}$

Turning back to the relationship between Adorno's aesthetic theory and Sevim Burak's theatre, Adorno is against the "realist" theory of Lukàcs in that of Adorno, although not neglecting the role of sociocultural factors in an artist's work, emphasizes the significance of "import" over "function", which proposes that political or economic functions of an artwork result from the "import" or "form" of the artist, in line with his theory of "negative dialectics" based on the negation of so-called reality. ${ }^{28}$ Rabaté warns us that Adorno's negativity "should

25 In the short story column of August/September 2019 issue (pages 140-142), the sentence "you are destroying reality" is used for five different reviews, to explain why these stories were not published in the magazine. In the December 2018/January 2019 issue, the reviewer says "A short story writer should seek for reality and thus for believability in a story. Setting, time, and characters serve to this end" (141).

26 In the December 2018 issue, Jale Sancak criticizes a social media comment about her with the words "For months, I have been trying to comment on the stories sent to me- sometimes unwillingly and getting bored with it- I am spending my time on this. And my only purpose is to make people write better stories. So, what is wrong with putting some rules to story writing? You might think that socialist realism and stylistic rules are old fashioned but that is the way I prefer reading stories".

27 Demirtaş, Postyapısalcı Edebiyat Kuramı: Sevim Burak, Edebiyatta Bir Tekillik Düşünürü, 161.

28 Zuidervaart, "Theodor W. Adorno". 
not be confused with nihilism" 29 though, reminding Adorno's own definition of negativity: "Works of the highest level of form that are meaningless or alien to meaning are more than simply meaningless because they gain their context through the negation of meaning". ${ }^{30}$

Sevim Burak's debut play "Sahibinin Sesi” [His Master's Voice] embodies this aesthetic approach with its use of anti-realistic elements within the play and fragmented language described as "a language unique to the playwright" by Demirtaş. ${ }^{31}$ This form could be clarified better with some examples from His Master's Voice. The play opens with Bilal observing the neighbourhood with binoculars and then he starts talking as if he were a reporter. However, it is not clear whether he is talking to himself or addressing the audience: "Ziya Bey is coming... Monsieur Verdu ... favourite of the widows in our neighbourhood... Blue beard... Blue beard... Oh...Oh... What am I seeing? The midwife ... Sorry, The Midwife Madame Anastasya". ${ }^{2}$ Even from these first lines, Burak makes it clear for the audience that Bilal has psychological problems, and in terms of form as Güçbilmez claims, Burak presents Bilal's character aligned with Heidegger's theatricality; Bilal is both the seer and the seen. ${ }^{33}$ Thus, in a way Burak demolishes the so-called "fourth wall" on the stage with this portrayal. Similarly, on the next page, Burak openly indicates in the stage directions that Bilal talks directly to the audience: "I went to my father's house crossing to Istanbul by 8:50 ferry. I learnt that my father spent the night sleepless (pauses) After visiting the grave of my mother, I went up to Beyoğlu taking the tram from Fatih...". ${ }^{34}$

This character portrayal is quite different from the characters of realist theatre who act as if there were no audience. Another stylistic feature is presented on the same page when Bilal starts talking about his father's dream. His father's dream is animated on the stage with a changing of light into blue, and throughout the scene we understand from the stage directions that the characters act as if they were animals: "Zembul is in a strange dress made from the furs of a wild animal... tearing the furs...Ziya Bey and Zembul imitating the acts and sounds of an animal...this scene should be exaggerated as much as possible...Zembul's voice is like a cat meowing... Ziya Bey as if barking... ". ${ }^{35}$ In this scene, Bilal also takes part in his father's dream; thus, as aforementioned, once again he is both the seer and the seen, or this time both the teller and the told. This is one of the scenes in which dream and reality are intertwined.

29 Jean-Michel Rabaté, "Philosophizing with Beckett: Adorno and Badiou", in A Companion to Samuel Beckett, Ed. S.E. Gontarski (Singapore: Wiley\&Blackwell, 2010), 97.

30 Adorno, Aesthetic Theory, 12.

31 Demirtaş, Postyapısalcı Edebiyat Kuramı: Sevim Burak, Edebiyatta Bir Tekillik Düşünürü, 159.

32 Sevim Burak, Sahibinin Sesi (İstanbul: Yapı Kredi Yayınları, 2020), 7.

33 Beliz Güçbilmez, “Tekinsiz Tiyatro: Sahibinin Sesi / Sevim Burak’ın Metninde Tekinsiz Teatrallik ve Minör Ses'in Temsili. Theatre of the Uncanny: His Master's Voice/ The Uncanny Theatricality and The Representation of the Minor Voice in S. Burak's Text”, Tiyatro Araştırmaları Dergisi, 16 (2003), 4-17.

34 Burak, Sahibinin Sesi, 8.

35 Ibid., 9. 
Towards the end of Act I, Bilal's father dies; however, the scene is not a sentimental one unlike a death scene in a realist play but presented rather as a regular phenomenon. Bilal continues reporting to the audience how his father died and, quite relaxed, lies on his father's bed. This is the point where the play takes a different turn with the prick of a needle. While getting ready to sleep after reporting the funeral, he suddenly jumps: "Owww... There is something in my heel... God damn.... This is a needle. Who has put it here? It was under my father's bed. It is in my heel. It needs to be taken out. But how?... Where?...Where?... Where?... It is no visible. God damn... It is lost...It is lost... ". ${ }^{36}$ The needle might be interpreted as a symbol for his feeling of guilt; however, Güçbilmez does not agree with this and claims that the needle does not have a metaphorical meaning, but rather Bilal himself turns into a needle which constantly pricks to himself. ${ }^{37}$ Bilal becomes a whole with the needle, and the needle becomes a part of him. Following this, he starts hearing voices: "Psst...Don't hide yourself behind the curtains... I can see you are there...". ${ }^{38}$ The delusions in the first Act of the play turn into voices in the second Act as Şeyben also explains. ${ }^{39}$ His madness moves through his body and captivates him as the needle.

The transitions among the scenes are also worth mentioning to understand Burak's theatrical style. Towards the middle of Act I, Zembul gets furious when Bilal throws their neighbour Anastasya, who wants to help Zembul, out of the house:

ZEMBUL: Bastard! Bastard! You are a bastard...I can't look at anyone's face now. You have shown me up...I will hang myself. I want to get rid of this man! (Zembul starts tearing her clothes off. She gets mad. Bilal looks around him as if seeking for help. Zembul screams) Help! They are killing me.40

Following this scene, however, Bilal closes the curtains, and the stage darkens. When the stage light is on again, we see a completely different scene where Bilal is reporting the events of that day. Thus, Burak's play does not follow a linear plot and scene development.

These dream scenes, animalized characters, the needle walking through Bilal's body up to his heart to kill him during the play, and the development of the scenes all elucidate Adorno's "import" idea which challenges the representational form of literature in that these stylistic experiments do not aim to represent an objective reality but rather to present situations rooted in a socio-cultural background.

36 Ibid., 45 .

37 Güçbilmez, “Tekinsiz Tiyatro: Sahibinin Sesi / Sevim Burak’ın Metninde Tekinsiz Teatrallik ve Minör Ses'in Temsili. Theatre of the Uncanny: His Master's Voice/ The Uncanny Theatricality and The Representation of the Minor Voice in S. Burak's Text", 14.

38 Burak, Sahibinin Sesi, 46.

39 Burcu Yasemin Şeyben, "(In)sight of Things: An Analysis of the Relation between Subjectivity and Reality in His Master's Voice”, Third Text, 26 (2012), 745-755.

40 Burak, Sahibinin Sesi, 20. 
The most prominent reflection of this socio-cultural background can be seen in Zembul's having two names - a reference to her Jewish background (Sümbül and Zembul) - Bilal's schizophrenic delusions, and his hostility towards "the Other" (Jewish neighbours). Güçbilmez supports this argument as well explaining that Bilal has hostile feelings towards anyone who is not like him and feels trapped in a neighbourhood inhabited mostly by these people. ${ }^{41} \mathrm{On}$ Act II, Bilal looks out of the window and says: "Here is the vulgar people. I will wait holding my revolver. I will murder these common people one by one. I will kill all of them" ${ }^{42}$, which exemplifies Bilal's hatred towards the neighbours. On Act I, while talking to Muzaffer Seza's ghost, Bilal says: "I never sleep without locking my door. I don't have children, cats, or dogs at home. When there is any kind of noise in the house, it frustrates me and I start shouting" ${ }^{43}$ which shows that his hatred actually stems from fear. This hatred/fear is not only an individualistic one but also a form of xenophobia embodied in Bilal's character and touches upon a social problem, discrimination against minorities specifically Jewish people. Güçbilmez also refers to a Turkish law dated 1932, which restricts the work permits of non-Turkish citizens, as an influence on Burak's play. ${ }^{4}$

Thus, Burak is experimenting with the theatrical style in different ways; however, this does not necessarily mean that Burak's form is completely individualistic without a sociohistorical background; in contrast, it is rooted in the author's Jewish background and the social conditions of the country as both Güngörmüş ${ }^{45}$, and Demirtaş ${ }^{46}$ also underlined. Thus, in accordance with Adorno's "negative dialectics" theory, although sociohistorical elements and objective reality constitute the foundation of Sevim Burak's theatre, Burak negates this objective reality through her form rather than represent it.

The emphasis on form put forth by Adorno, and embodied in Burak, differs from the formalist approach which seeks "art for art's sake". As Dellaloğlu explains: "For Adorno, an artwork is not a mirror reflecting real life; it is rather a platform where alternative lives emerge...Adorno always attached a negative meaning to "social". And what prevents art from sharing the negativity of this "social", although living in it, is the aesthetic form... An artwork is political in as much as its form deviates from the social reality. " ${ }^{47}$ Dellaloğlu's emphasis on the political aspect of non-representational or "modern" art forms responds to the most common

41 Güçbilmez, “Tekinsiz Tiyatro: Sahibinin Sesi / Sevim Burak’1n Metninde Tekinsiz Teatrallik ve Minör Ses’in Temsili. Theatre of the Uncanny: His Master's Voice/ The Uncanny Theatricality and The Representation of the Minor Voice in S. Burak's Text", 15.

42 Burak, Sahibinin Sesi, 47.

43 Ibid., 32.

44 Güçbilmez, “Tekinsiz Tiyatro: Sahibinin Sesi / Sevim Burak'ın Metninde Tekinsiz Teatrallik ve Minör Ses’in Temsili. Theatre of the Uncanny: His Master's Voice/ The Uncanny Theatricality and The Representation of the Minor Voice in S. Burak's Text", 15.

45 Güngörmüş, foreword to Bir Usta, Bir Dünya: Sevim Burak. One Master, One World: Sevim Burak.

46 Demirtaş, Postyapısalcı Edebiyat Kuramı: Sevim Burak, Edebiyatta Bir Tekillik Düşünürü.

47 Soykan, Keskin \& Dellaloğlu, "Adorno ve Yapıtı", 37. 
criticism to modern art that an artwork which prioritizes form over content is apolitical. In contrast to this argument, as Dellaloğlu claims, the political characteristic of modern art forms is rooted in their formalistic features in the sense that they pose a challenge to the status quo, namely traditional art forms, and through this to the dominant ideology, which suggests that an artwork's political aspect is not related to its subject matter, but rather to its form.

The use of language requires emphasis in further analysing Adorno's aesthetic theory and form. Adorno and Horkheimer pose a serious critique towards the Enlightenment focusing on its self-destructive nature, which cannot be explained through traditional linguistic forms and conceptual frameworks urging a fragmented and unique artistic language. ${ }^{48}$ This use of language emerges as an inherent characteristic of Sevim Burak's theatre both in Sahibinin Sesi [His Master's Voice] and Işste Baş Işste Gövde Işste Kanatlar [Here's the Head, Here's the Body, Here are the Wings], which is reflected in the below passage from Sahibinin Sesi [His Master's Voice]. Bilal's fragmented language, uncompleted sentences, and the use of punctuation are exemplary of Burak's non-traditional use of language:

Bilal: ... Wedding...Hi wedding...They will unite us...Haa..Haa..Haa / That notorious child... The child in the dream. Rachitic child. Fatherless ...child... ${ }^{49}$

As Demirtaş argues "Burak is interested in the transformative power of the words rather than their metaphorical qualities. While doing this, she forms each and every sentence in a way to bear multiple meanings. A new detail is realized in every single reading. " ${ }^{0}$ Demirtaş defines Burak's language as "rhizomatic" meaning that each piece is linked to the others forming a chaotic whole. However, attaching a pejorative meaning to the word "chaotic" would be misleading since the word implies a chaos as defined by Samuel Beckett: “... there will be new form, and that this form will be of such a type that admits the chaos and does not really try to say it is something else... To find a form that accommodates the mess, that is the task of the artist now. "'51 Based on this definition, it would not be wrong to claim that Sevim Burak's quest for a new form in theatre parallels that of Beckett whom Burak admired.

All of the aforementioned qualities of Sevim Burak's theatre - her non-representational style, unique language, use of unrealistic elements which challenge the traditional plot development - can be said to reflect Adorno's theory of negative dialectics and aesthetic understanding. However, Sevim Burak's stance as a playwright in the history of Turkish theatre also requires an analysis of her art in terms of Adorno's ideas on "culture industry".

48 Horkheimer \& Adorno, Dialectic of Enlightenment: Philosophical Fragments, 63-93.

49 Burak, Sahibinin Sesi, 17.

50 Demirtaş, Postyapısalcı Edebiyat Kuramı: Sevim Burak, Edebiyatta Bir Tekillik Düşünürü, 172.

51 Tom F. Driver, Interview with Samuel Beckett, in Samuel Beckett: The Critical Heritage, Ed. Lawrence Graver and Raymond Federman (London: Routledge \& Kegan Paul, 1979), 46. 


\section{Sevim Burak and "Culture Industry"}

Adorno's theory on "culture industry", in other words his "critical social theory" is based on Marx's "fetishism of commodities" idea. Marx, emphasizing the distinction between "surplus value" and "use value" claimed that surplus value of a commodity, commonly confused with the use value, results from the exploitation of the capitalist system leading to a commodity fetishism. ${ }^{52}$ Applying Marx's ideas to the cultural and artistic fields, Adorno claims that art's autonomy has been renounced in the late capitalist system and that marketability has been granted privilege over artistic value; in Adorno's words "Culture now impresses the same stamp on everything. Films, radio, and magazines make up a system which is uniform as a whole and in every part. Culture has become openly, and defiantly, an industry obeying the same rules of production as any other producer of commodities". ${ }^{53}$

However, interpreting Adorno's criticism of the culture industry merely as an opposition to art's transformation through technological developments would be misleading as Adorno puts the real problem as setting "value standards", which basically refers to the adoption of certain artistic forms and expulsion of the non-traditional others. This approach, for Adorno, undermines the significance of "style", the primary characteristic of an artwork. While underlining the problem with adopting the existing forms as absolute, Adorno emphasizes the significance of the non-traditional as "It is only in struggle with the tradition, a struggle precipitated in style, that art can find expression for suffering...the great work of art has always negated itself, the inferior work has relied on its similarity to others, the surrogate of identity. "54

Adorno's definition of "culture industry" could well apply to the condition of literary circles in the 1950's-60's Turkey - and even today-, when Sevim Burak emerged as a figure to challenge the dominant form, namely socialist realism. Although great works of socialist realist literature were produced during this period, it would not be wrong to say that it turned out to be the most marketable genre, which ended up with the dismissal of other forms, thus understanding Sevim Burak's position in Turkish literature also requires an evaluation of the industrial and ideological factors of the time.

1950 was a turning point for the country both in terms of politics and literature as this was the year when the opposition party, Democrat Party, came to power following the 27year rulership of the Republican Party (CHP). This was a tremendous change in the country as the new ruling party brought "a new process of leadership selection, social mobilization, and broader popular participation" ${ }^{55}$ Karpat, in another work on Turkish literary modernism explains the role of the literary circles preceding the 1950s with these words:

52 Karl Marx, Capital Volume I, Tr. Ben Fowkes, (London: Penguin Classics, 1990), 28.

53 T.W. Adorno, The Culture Industry, Ed. J.M. Bernstein, (London; New York: Routledge Classics, 2005), 9.

54 Horkheimer \& Adorno, Dialectic of Enlightenment: Philosophical Fragments, 103.

55 Kemal H. Karpat, "Political Developments in Turkey, 1950-70”, Middle Eastern Studies 8/3 (1972), 349-375. 
Contemporary social literature places itself in the role of spokesman for the entire society and looks upon all individuals, intellectual and layman alike, as responsible for the good of that society if only for the reason of having been born in it. The prime responsibility is placed upon the intellectual, who should provide enlightened leadership with due consideration to the actual needs of society and respect for its way of life. ${ }^{56}$

As Karpat puts it, the intellectuals including the writers were given a role of educating and leading the public through their works during this period. Karpat underlines that this trend changed into an interest in the solution and depiction of village problems in the literature of the 1950s. ${ }^{57}$ Karpat dates the beginning of this trend to Mahmut Makal's notes on village life published in Our Village (1950). Upon the great public interest the work received, Makal wrote three more books on village life in Turkey, a trend followed by other literary figures such as Talip Apaydın, Fakir Baykurt, and Mehmet Başaran. ${ }^{58}$

This first group of village writers was followed by an even more popular second group including Yaşar Kemal, Orhan Kemal, Tahir Kemal, Samim Kocagöz, and İlhan Tarus. This "village literature" trend was a tremendous success and some of the aforementioned writers such as Yaşar Kemal and Orhan Kemal proved to be among the greatest writers of Turkish literature; however, Sevim Burak, who started writing during the same time period, claimed in many of her letters that it also precluded the emergence of other literary forms and themes. Erdağ Göknar, in his study on canonical literature in Turkey, also underlines that Turkish literature often served political purposes in different periods rather than artistic ones, and thus the literary works were expected to follow this popular tendency. For Göknar, the novel for example "was used as a didactic tool for matters of poverty, education, and the social position of women" in 1910s and then "as tools for nationalisation" in 1920s and 30s, and "as tools for Anatolian social consciousness" in 1950s and 60s. ${ }^{59}$ Although not in a critical sense, Talat Halman also underlines that representing everyday life has been the common and predominant tendency in the history of Turkish fiction. ${ }^{60}$ This constant use of literature for different political and popular purposes, or for representing everyday life was the point that Burak protested against. For example, in a letter dated 1982, she criticizes Yaşar Kemal harshly:

There is someone called Yaşar Kemal, who has an international fame. For me, he is just worthless. I can't stand reading a line written by him. He is just exploiting the traditions of Anatolia. And Europe, of course, supports him... They have been advertising him for years.

56 Kemal H. Karpat, "Social Themes in Contemporary Turkish Literature", The Middle East Journal, 14/1, (1960), $29-44$.

57 Ibid., 40.

58 Ibid., 40.

59 Erdağ Göknar, "The Novel in Turkish: narrative tradition to Nobel prize" in The Cambridge History of Turkey: Turkey in the Modern World, Ed. Reşat Kasaba (Cambridge University Press, 2006), 472-503.

60 Talat Sait Halman, "Modern Turkish Literature: Disorientation and Reorientation”, Books Abroad, 46 (1972), 226-231. 
That is a kind of trade for me. He even insists that he will be awarded Nobel prize one day... Anyway... I am not that kind of a writer. Everybody knows it. ${ }^{61}$

As Demirtaş puts it, Sevim Burak, on the other hand, writes for "a reader who is not included in the commercial scope of art. Burak is against the transformation of literature into a touristic and cultural object, and she defends the creative power of literature against traditional canonic literature. "62 Demirtaş underlines the revolutionary aspect of Sevim Burak's literature in challenging the norms of traditional canonical literature both in terms of the audience addressed and the new form.

Agreeing with Demirtaş, Güngörmüş claims "She [Sevim Burak] is the first writer in our literature who leaves everything aside to get to the essence of the work, even going so far as to bring before us a poster of the alphabet where we can feast our eyes on each letter". ${ }^{63}$ Güngörmüş focuses on Burak's experiments with linguistic forms especially in her short stories, also emphasizing Burak's commonly mentioned "montage" technique in creating her works. Burak pins the pieces of her manuscripts on curtains and finalizes her works through a long process of editing and assemblage, which has often been misinterpreted as a coincidental technique. Thus, not only Burak's end product but also her creative process was a challenge to the norms of the culture industry. Burak's own words explaining the audience she aims to address to are also worth mentioning: "I won't write for the shrewd people-I will write for the ones who have gone senile early-for the dreamers-for the ones preparing to leave this world... I will share this world only with the ones who have lost their minds. I will only write to the ones who have gone mad because of love, to schizophrenics, to extremely romantics, to extremely sadists...to lunatics. " 64

However, Burak's montage technique should not be confused with the Soviet montage theory practiced by Soviet filmmakers such as Eisenstein, aiming at political propaganda rather than artistic experiment. As Maria Gough, citing Klucis, explains there are two distinct lines in terms of using montage technique: the first one is used mostly by Dadaists and expressionists as an artistic innovation; however, the second one created by the Soviet artists serves to the ends of political propaganda. ${ }^{65}$ Mueller describes this distinction through a reference to montage in Brecht, claiming that "montage" in modern art is used as a reactionary aesthetic technique against the traditional forms; however, Soviet artists abused the technique as a means of political propaganda, removing it from its original purpose. ${ }^{66}$ Obviously, Burak's use of

61 Sevim Burak, Mach One'dan Mektuplar, 140.

62 Demirtaş, Postyapısalcı Edebiyat Kuramı: Sevim Burak, Edebiyatta Bir Tekillik Düşünürü, 171.

63 Güngörmüş, foreword to Bir Usta, Bir Dünya: Sevim Burak. One Master, One World: Sevim Burak, 11.

64 Burak, Mach One'dan Mektuplar, 24.

65 Maria Gough, "Back in the USSR: John Heartfield, Gustavs Klucis, and the Medium of Soviet Propaganda", New German Critique, No.107, (2009). 133-183.

66 Roswitha Mueller, "Montage in Brecht”, Theatre Journal, Vol. 39, No.4, (1987), 473-486. 
montage technique did not aim to serve political propaganda as the author declared on various occasions, including her letters that she was against the use of art for political purposes. As Güngörmüş also puts it "Underneath her sentence-cutting, her sliding of lines one on top of another, her inversion of familiar stretches of time, lies a very important quest that is almost a life and death issue. This is a search for meaning through the use of style." ${ }^{67}$

Unlike Sevim Burak's targeted audience mentioned in the quote, works of art are produced for masses in Adorno's “culture industry", thus Adorno frequently makes use of the examples of television and movies; however, his ideas could be applied to all artistic genres including literature. Sevim Burak's own letters prove to be the most overt evidence of Burak's disappointment with the culture industry, parallel with Adorno. In a letter to Güzin Dino, Burak complaints that her play has been neglected by the literary circle as it does not have an explicit social message, unlike the plays of Yaşar Kemal and Güngör Dilmen, underlining that her plays are not "marketable" enough ${ }^{68}$, which reminds of Adorno's ideas on artistic commodities.

\section{Conclusion}

Sevim Burak has been one of the most revolutionary literary figures in the twentieth century Turkish literature not only with her short stories, but also with her plays and the unique theatrical style she created. However, she has mostly been neglected or misunderstood, and her works have mostly been explored with the medium of traditional literary forms, which led to a superficial approach to Burak's art. This tendency has changed recently, and it is important to note that Burak's art attracts the attention of novice scholars.

In this paper, I aimed to contribute to the literature on Sevim Burak through a philosophical reading of her theatre, an aspect which has commonly been ignored. In doing this, Sevim Burak's near contemporary Adorno's ideas on aesthetics and culture paved the way for reading Burak as a revolutionary literary figure. Burak's art, especially her theatre, opposes to the representation of "real" life, by negating the so-called representable, in line with Adorno's "negative dialectics" theory.

Art's purpose for Burak is not to represent the already visible but rather to create a unique world of its own through an artistic form. Burak creates this form in theatre through her use of language, her schizophrenic characters, and anti-realist elements embedded into reality. By creating this unique form, she challenges the canonical style imposed upon by the literary circles just as Samuel Beckett, Eugene Ionesco or Harold Pinter did in European literature. In that sense, her art proved to be a challenge to "culture industry" which focuses on the marketable rather than the artistic, explaining why she was expelled, by many, from the literary

67 Güngörmüş, foreword to Bir Usta, Bir Dünya: Sevim Burak. One Master, One World: Sevim Burak, 13.

68 Burak, Mach One'dan Mektuplar, 31. 
society. Burak's art proves that the protest quality of an artwork cannot merely be attributed to its subject matter or the message it conveys, but an artist could produce protest work through the use of stylistic features which challenge the set rules; thus, understanding Sevim Burak's art requires more than summarizing or closely reading the content of her works through the norms of traditional forms. Only through wider philosophical, aesthetic, political, and social perspectives, can Sevim Burak's art be located in the scope of world literature.

Peer-review: Externally peer-reviewed.

Conflict of Interest: The author has no conflict of interest to declare.

Grant Support: The author declared that this study has received no financial support.

Hakem Değerlendirmesi: Dış bağımsız.

Çıkar Çatışması: Yazar çıkar çatışması bildirmemiştir.

Finansal Destek: Yazar bu çalışma için finansal destek almadı̆̆ını beyan etmiștir.

\section{BIBLIOGRAPHY / KAYNAKÇA}

Adorno, T.W. Aesthetic Theory, Translated by R. Hullot-Kentor. Minneapolis: University of Minnesota Press, 1997.

Adorno, T.W. Culture Industry. Edited by J.M. Bernstein. London and New York: Routledge Classics, 2005.

Adorno, Theodor. "Reconciliation under Duress", in Aesthetics and Politics. Edited by Ronald Taylor. London; New York: Verso Publishing, 1980.

Adorno: Kitle, Melankoli, Felsefe- Cogito Dergi. Edited by E. Efe Çakmak. İstanbul: Yapı Kredi Yayınları, 2020.

Aracagök, Zafer \& Yalım, Burcu. "Spectacle, Speculative, Spectile: Situations in Sarah Kane, Sevim Burak etc.", Third Text, (2010). 437-444.

Bir Usta Bir Dünya: Sevim Burak. Edited by Filiz Özdem. İstanbul: Yap1 Kredi Yayınlar1, 2013.

Burak, Sevim. Sahibinin Sesi. İstanbul: Yapı Kredi Yayınları, 2020.

Burak, Sevim. Mach One’dan Mektuplar. İstanbul: Palto Yayınları, 2014.

Chris Thornhill and Ronny Miron, "Karl Jaspers", The Stanford Encyclopedia of Philosophy, Edited by Edward N. Zalta (Spring 2020 Edition),

https://plato.stanford.edu/archives/spr2020/entries/jaspers/.

Cough, Maria. "Back in the USSR: John Heartfield, Gustavs Klucis, and the Medium of Soviet Propaganda", New German Critique, No.107. (2009), 133-183.

Demirtaş, Mustafa. Postyapısalcı Edebiyat Kuramı: Sevim Burak Edebiyatta Bir Tekillik Düşünürü. İstanbul: Otonom Yayınları, 2015.

Dow, Arthur Wesley. "Modernism in Art”, The American Magazine of Art 8. (1917), 113-116.

Driver, Tom F. Interview with Samuel Beckett, in Samuel Beckett: The Critical Heritage, Edited by Lawrence Graver and Raymond Federman. London: Routledge \& Kegan Paul, 1979. 
Göknar, Erdağ. "The Novel in Turkish: narrative tradition to Nobel prize" in The Cambridge History of Turkey: Turkey in the Modern World, Ed. Reşat Kasaba. Cambridge University Press, 2006, 472-503.

Gümüş, Şeyma. “Sevim Burak'ın Queer Nesneleri: Yanık Saraylar'da Eşya-İnsan İlişskileri, Öznellik ve Ötekilik", Monograf 14. (2020), 60-82.

Güngörmüş, Nilüfer. "Sanatçının Annesinin Kızı olarak portresi", YKY Feminizm Üzerine Konuşmalar Dizisi, Kadınlar, Kimlikler, Hafizalar, Psikanaliz ve Feminizm Paneli, (2005).

Güçbilmez, Beliz. "Tekinsiz Tiyatro: Sahibinin Sesi/Sevim Burak'ın Metninde Teatrallik ve Minör Sesin Temsili”, Tiyatro Araştırmaları Dergisi 16. (2003), 4-17.

Halman, Talat Sait. "Modern Turkish Literature: Disorientation and Reorientation", Books Abroad, 46 (1972), 226-231.

Horkheimer, M. \& Adorno, T.W. Dialectic of Enlightenment: Philosophical Fragments, Edited by G.S.Noerr, Translated by E. Jephcott. Stanford: Stanford University Press, 2002.

Karpat, Kemal H. "Social Themes in Contemporary Turkish Literature", The Middle East Journal, 14/1, (1960), 29-44.

Karpat, Kemal H. "Political Developments in Turkey, 1950-70", Middle Eastern Studies 8/3 (1972), 349-375.

Kılınç, Ahmet. “Sevim Burak’’n Küçürek Öykücülüğü”, Turkish Studies (2011), 1983-1994.

Koçakoğlu, Bedia. Aşkın Şizofrenik Hali Sevim Burak. Konya: Palet Yayınları, 2009.

Koçakoğlu, Bedia. "Sevim Burak’1 Besleyen Damarlar”, Selçuk Üniversitesi Edebiyat Fakültesi Dergisi, 17. (2007), 45-59.

Lambert Zuidervaart, "Theodor W. Adorno", The Stanford Encyclopedia of Philosophy, Edited by Edward N. Zalta (Winter 2015Edition),

https://plato.stanford.edu/archives/win2015/entries/adorno/.

Lukàcs, Georg. "Realism in the Balance", in Aesthetics and Politics. Edited by Ronald Taylor. London; New York: Verso Publishing, 1980.

Marx, Karl. Capital Vol. I. Translated by Ben Fowkes. London: Penguin Classics: 1990.

Notos Dergi. İstanbul: Notos Yayınlar1, Ağustos-Eylül 2019.

Notos Dergi. İstanbul: Notos Yayınlar1, Aralık 2018-Ocak 2019.

Rabaté, Jean-Michel. "Philosophizing with Beckett: Adorno and Badiou", in A Companion to Samuel Beckett, edited by S.E. Gontarski, 97. Singapore: Wiley\&Blackwell, 2010.

Roswitha Mueller, "Montage in Brecht", Theatre Journal, Vol. 39, No.4. (1987), 473-486.

Şeyben, Burcu Yasemin. "(In)sight of Things: An Analysis of the Relation between Subjectivity and Reality in His Master's Voice", Third Text, 26 (2012), 745-755.

Varlık Dergisi. İstanbul: Varlık Yayınları, Aralık 2018. 
